\title{
Components For Hybrid Vehicles: Results of the IEA Annex VII "Hybrid Vehicle" Phase III
}

\author{
Fiorentino Valerio Conte*, Francois Badin**, Patrick Debal***, Mats Alaküla****
}

\begin{abstract}
This paper describes the experiences made inside the Annex VII "Hybrid Vehicle" Phase III of the IEA Implement Hybrid \& Electric Vehicle. In particular, the paper focuses on the Components that have been investigated by the working group. The development of a vehicle with an electric traction system, like HEV has to deal with the introduction of components which are not present in Conventional Vehicle (CV), or which, even if present in $\mathrm{CV}$, they must undergo modifications for an HEV application, like for instance the cooling compressor.

The working-group has singled out 4 main interesting areas which have these critical components: Fuel Converters, Drives, Energy Storage, and Auxiliaries. The issues related to these areas must be properly solved for achieving the needed HEV's performances. Inside the Annex VII the experts have discussed it, and the paper gives an overview of this process.
\end{abstract}

Keywords: Hybrid Electric Vehicle, Auxiliary System, Components

\section{IEA ORGANIZATION}

The International Energy Agency (IEA), based in Paris, is an autonomous agency linked with the Organization for Economic Co-operation and Development (OECD). The IEA is organized as forum with 26 Member countries. The members have done commitments for addressing the oil supplies emergencies. Within platform like the IEA they take joint actions, they coordinate their energy policies, and the share information about environment and energy.

Annex VII "Hybrid Vehicles" is one of six annexes of the IEA "Implementing Agreement for Hybrid and Electric Vehicle Technologies and Programmes". This Agreement is an international collaboration program in which currently eight members are participating. Each annex deals with different aspects related to electric, fuel cell and hybrid vehicles. The participating countries in the Hybrid and Electric Vehicle Implementing Agreement are: Austria; Belgium; France; Italy; The Netherlands; Sweden; Switzerland; United States.

\section{THE ANNEX VII "HYBRID VEHICLE"}

The Annex VII "Hybrid vehicle" deals in detail with the hybrid vehicle technology and their related issues.

* Arsenal Research, Giefinggasse 2, Vienna, Austria,

$\mathrm{T}+43-(0) 50$ 550-6217, F +43-(0)50 550-6595,

valerio.conte@arsenal.ac.at

** INRETS, Avenue François Mitterrand 25, Lyon, France,

$\mathrm{T}+33-4-721424$ 74, F +33-4-72 3768 37, badin@inrets.fr

*** VITO, Boeretang 200, Mol, Belgium

T+32- 14335843 , F +32- 14321185 , patrick.debal@vito.be

**** Lund Institute of Technology, P O Box 118 Lund, Sweden,

T +46 - 462229284 ,F +46 - 46142114 , Mats.Alakula@iea.lth.se
Already in the nineties the IEA Implementing Agreement on Hybrid and Electric Vehicle has started this annex, and right now the third phase, named Phase III, is going on.

The Annex VII work plan has three different areas of interests. One is the Plug-In Hybrid Vehicle investigation. The Plug-In Hybrid Vehicle is a variant of hybrid vehicle characterized by a charge depleting strategy of the battery and consequently a more capacious battery pack. Another area of interest is the information exchange for improving the dissemination of know-how within the research community and for avoiding the spreading out of misleading information about the hybrid thematic, which is still not totally understood by the public.

The last area of interest of the Annex VII "Hybrid vehicle" is the components for hybrid electric vehicles.

The development of a vehicle with an electric traction system, like $\mathrm{HEV}$ has to deal with the introduction of components which are not present in Conventional Vehicle (CV), or which, even if present in $\mathrm{CV}$, they must undergo modifications for an $\mathrm{HEV}$ application.

Therefore a specific task of the Annex is dedicated to the component investigation for HEV application.

The task leader is Arsenal Research, an Austrian enterprise in behalf of the BMVIT (Austrian Federal Ministry for Transportation, Innovation and Technology).

\section{COMPONENTS TASK}

There are an infinite number of HEV driveline configurations, and it would be impossible to single out 
each of them. Besides the hybrid electric vehicle market is relatively new therefore only few suppliers are ready to provide specifically designed parts which fit the hybrid vehicle manufacturer's requirements. This infinite number of HEV drivelines and this lack of components competitors do not help the component cost reduction which is necessary for having affordable and reliable HEV vehicles. Therefore the work done by the hybrid experts within the Annex VII is essential for pointing out the component main issues and for benchmarking the present state of the art of the component technology.

The international working-group has defined 4 main areas where there are critical components:
1. Fuel Converters
2. Drives
3. Auxiliaries
4. Energy Storage

\section{FUEL CONVERTER}

For having a vehicle with low emissions and good fuel consumption it is essential that the conversion of the oil energy in mechanical energy is as much efficient as possible. For this reason the primary energy converter has been investigated.

INRETS is the sub task Fuel Converter leader, and it represents France in behalf of ADEME in this technical working group. The work has to overcome the difficulties of having many internal combustion configurations, spark ignition engines, compressed ignition engines, both in supercharged or in aspirated configuration, as well as the different type of fuels, like gasoline, diesel, LPG, CNG, bio-fuels. Moreover there are different transmission configurations, manual, automatic and automatised gearboxes, as also different drivelines like serial, parallel, power-split.

For this wide range of configurations it is impossible to single out the optimal solution. Each case should be investigated by itself taking into account also the not technical boundary conditions, especially the policies regulation, especially in term emissions constraints and taxations.

Thanks to the experience of the Annex members the trend for fuel converter technology could be pointed out, in particular it has been investigated the present engine state of art and the driveline configuration have been correlated with the emission and the performances.

In the following figures some results of the work are shown.
Table 1 Example of the Gasoline Engine Database

\begin{tabular}{|c|c|c|c|c|c|c|c|}
\hline \multicolumn{2}{|c|}{ Gasoline engines } & Type A & Type B & Type C & Type D & Type E & Type F \\
\hline Displacement & $\mathrm{cc}$ & 1124 & 1360 & 1587 & 1749 & 2237 & 1997 \\
\hline Injection & & \begin{tabular}{|l|} 
port multi \\
\end{tabular} & port multi & \begin{tabular}{|l} 
port multi \\
\end{tabular} & port multi & \begin{tabular}{|l|} 
port multi \\
\end{tabular} & direct \\
\hline Turbo & & 0 & 0 & 0 & 0 & 0 & 0 \\
\hline Max power & $\mathrm{kW}$ & 44,1 & 65 & 80 & 85 & 116 & 103 \\
\hline Max power & $\mathrm{cv}$ & 60,0 & 88,4 & 108,8 & 115,6 & & \\
\hline @ speed & $\mathrm{rpm}$ & 5500 & 5250 & 6200 & 5500 & 5500 & 6000 \\
\hline Max Torque & $\mathrm{Nm}$ & 94 & 133 & 147 & 159 & 217 & 192 \\
\hline @ speed & $\mathrm{rpm}$ & 3300 & 3250 & 3500 & 4000 & 4000 & 4000 \\
\hline Dry weight & $\mathrm{kg}$ & 80 & 89 & 115 & 137,5 & 137,5 & 137,5 \\
\hline Spec power & W/kg & 519 & 691 & 667 & 596 & 814 & 723 \\
\hline $\mathrm{CR}$ & & 10,5 & & & 10,8 & 10,8 & 11,5 \\
\hline Architecture & & $4 \mathrm{~L}$ & $4 \mathrm{~L}$ & $4 \mathrm{~L}$ & $4 \mathrm{~L}$ & $4 \mathrm{~L}$ & $4 \mathrm{~L}$ \\
\hline Valve nbr/cyl & & 2 & 4 & 4 & 4 & & 4 \\
\hline Best BSC & $\mathrm{g} / \mathrm{kWh}$ & & & & 263 & & 255 \\
\hline $\begin{array}{l}\text { Regulation } \\
\text { Std }\end{array}$ & & Euro 4 & Euro 4 & Euro 4 & Euro 4 & Euro 4 & Euro 4 \\
\hline Engine block & & $\begin{array}{l}\text { Light } \\
\text { alloy }\end{array}$ & $\begin{array}{l}\text { Light } \\
\text { alloy }\end{array}$ & Cast Iron & $\begin{array}{l}\text { Light } \\
\text { alloy }\end{array}$ & $\begin{array}{l}\text { Light } \\
\text { alloy }\end{array}$ & $\begin{array}{l}\text { Light } \\
\text { alloy }\end{array}$ \\
\hline Cylinder head & & $\begin{array}{l}\text { Light } \\
\text { alloy }\end{array}$ & $\begin{array}{l}\text { Light } \\
\text { alloy }\end{array}$ & $\begin{array}{l}\text { Light } \\
\text { alloy }\end{array}$ & $\begin{array}{l}\text { Light } \\
\text { alloy }\end{array}$ & $\begin{array}{l}\text { Light } \\
\text { alloy }\end{array}$ & $\begin{array}{l}\text { Light } \\
\text { alloy }\end{array}$ \\
\hline Camshaft & & 1 & 1 & 1 & 2 & 2 & 2 \\
\hline VVT & & No & No & No & No & No & No \\
\hline Lenght & $\mathrm{m}$ & 0,580 & 0,535 & 0,566 & 0,621 & 0,621 & 0,656 \\
\hline Height & $\mathrm{m}$ & 0,645 & 0,681 & 0,657 & 0,656 & 0,661 & 0,706 \\
\hline Width & $\mathrm{m}$ & 0,580 & 0,603 & 0,603 & 0,684 & 0,773 & 0,707 \\
\hline Spec power & $\mathrm{W} / \mathrm{I}$ & 203 & 296 & 357 & 305 & 366 & 315 \\
\hline 3 Way & & Yes & Yes & Yes & Yes & Yes & \\
\hline
\end{tabular}

Table 2 Example of the Diesel Engine Database

\begin{tabular}{|c|c|c|c|c|c|c|}
\hline \multicolumn{2}{|c|}{ Diesel engines } & Type G & Type $\mathrm{H}$ & Type I & Type L & Type M \\
\hline Displacement & $\mathrm{cc}$ & 2178 & 1997 & 1398 & 1560 & 1560 \\
\hline Injection & & D CR & D CR & D CR & D CR & D CR \\
\hline Pressure max & $\mathrm{b}$ & 1800 & 1600 & 1350 & 1600 & 1600 \\
\hline Injector & & & Piezo & & & \\
\hline Turbo & & 2 & 1 & 1 & 1 & 1 \\
\hline Turbo techno & & VGT & VGT & & & VGT \\
\hline Intercooler & & yes & yes & no & yes & yes \\
\hline Max power & $\mathrm{kW}$ & 125 & 100 & 50 & 66 & 80 \\
\hline Max power & $\mathrm{cv}$ & 170,0 & 136,0 & 68,0 & 89,8 & 108,8 \\
\hline @ speed & $\mathrm{rpm}$ & 4000 & 4000 & 4000 & 4000 & 4000 \\
\hline Max Torque & $\mathrm{Nm}$ & 400 & 320 & 150 & 215 & 240 \\
\hline @ speed & $\mathrm{rpm}$ & 1750 & 2000 & 1750 & 1750 & 1750 \\
\hline Dry weight & $\mathrm{kg}$ & & 162 & 105 & 120 & 120 \\
\hline Spec power & W/kg & & 599 & 455 & 528 & 640 \\
\hline $\mathrm{CR}$ & & & 18,1 & & & \\
\hline Architecture & & $4 \mathrm{~L}$ & $4 \mathrm{~L}$ & $4 \mathrm{~L}$ & $4 \mathrm{~L}$ & $4 \mathrm{~L}$ \\
\hline Valve nbr/cyl & & 4 & 4 & 2 & 4 & 4 \\
\hline Best BSC & $\mathrm{g} / \mathrm{kWh}$ & & & & & \\
\hline $\begin{array}{l}\text { Regulation } \\
\text { Std }\end{array}$ & & Euro 4 & Euro 4 & Euro 4 & Euro 4 & Euro 4 \\
\hline Engine block & & Cast Iron & Cast Iron & $\begin{array}{l}\text { Light } \\
\text { alloy }\end{array}$ & Light alloy & Light alloy \\
\hline Cylinder head & & Light alloy & Light alloy & $\begin{array}{l}\text { Light } \\
\text { alloy }\end{array}$ & Light alloy & Light alloy \\
\hline Camshaft & & 2 & 2 & 2 & 2 & \\
\hline VVT & & & & & & \\
\hline Lenght & $\mathrm{m}$ & 0,638 & 0,645 & 0,627 & 0,650 & 0,650 \\
\hline Height & $\mathrm{m}$ & 0,700 & 0,697 & 0,694 & 0,700 & 0,700 \\
\hline Width & $\mathrm{m}$ & 0,633 & 0,650 & 0,510 & 0,576 & 0,576 \\
\hline Spec power & W/I & & & & & \\
\hline Oxyd Cata & & Yes & Yes & Yes & Yes & Yes \\
\hline Part Trap & & Yes & Yes & No & Yes & No \\
\hline Remark & & & & $\mathrm{C} 2, \mathrm{C} 3$ & & \\
\hline
\end{tabular}

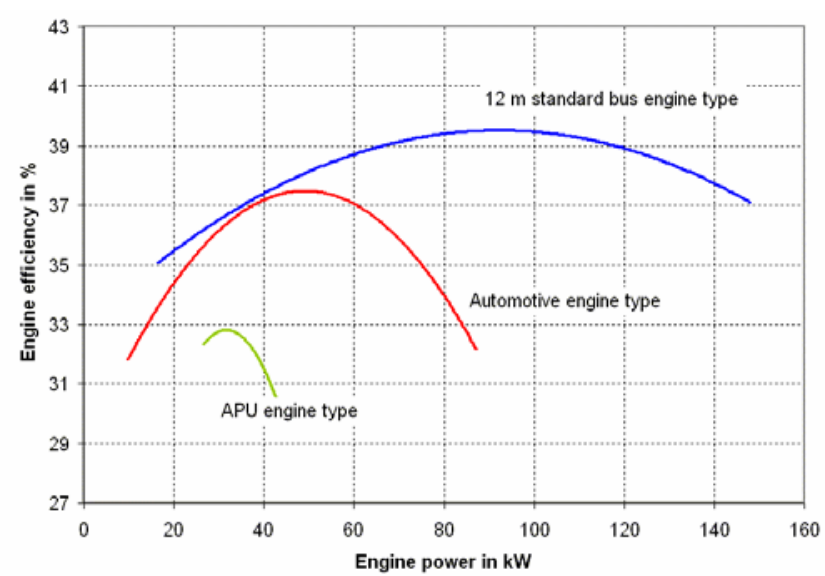

Fig. 1 Example of Diesel engine characteristics for different applications 


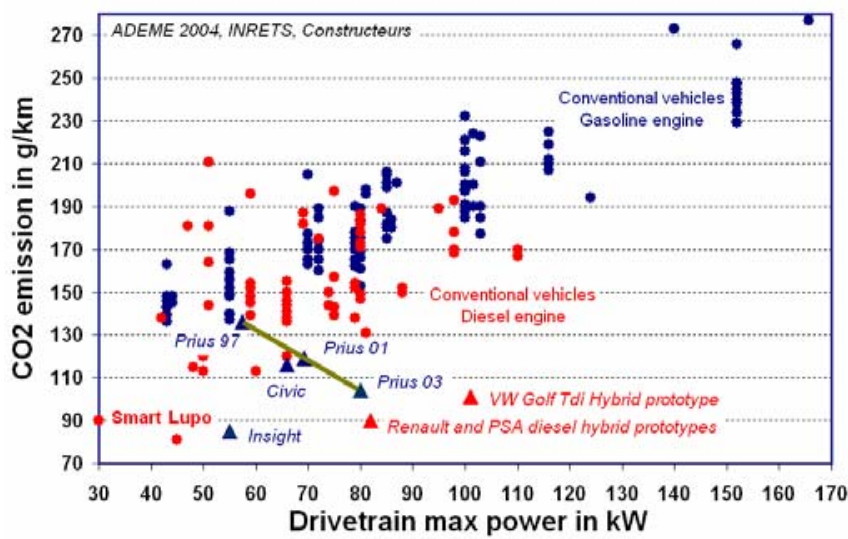

Fig. $2 \mathrm{CO}_{2}$ Emission related to the installed drivetrain maximum power

An extract of the developed engine database is shown in the table 1 and 2, with such spreadsheets it is possible to get an overview of the engines performances.

The figure 1 shows the test bench efficiency results of three different sizes of diesel engines. Such measurements give an assessment of the possible achievable efficiency for diesel engine and are important inputs for engine downsizing analysis.

Of course the efficiency consideration has to be related to the $\mathrm{CO}_{2}$ emissions that the engine makes during its operation. The figure 2 gives an overview of the emission performances of different vehicles, like hybrid electric vehicle, conventional gasoline vehicles and conventional diesel vehicles. Looking at this figure 2 it is clear the big advantages that the hybrid solution offers in terms of $\mathrm{CO}_{2}$ emissions.

\section{DRIVES}

The Drive technology are investigated, where with Drives technology it is intended the complex of the electric machine and the corresponding power electronic device used for driving the electric machine.

For the automotive industries this technology is relativly new, up to few years ago there were only few electrical machines installed in the car, and only two of them, the alternator and the starter motor have a significant, but still modest power rating.

This situation is changing rapidly, the electric machines are used in the driveline as well as for actuating large loads like the air conditioning compressor, moreover electric drive are always more adopted for actuating many small loads. Consequently the automotive electronic market growth-rate is almost $10 \%$ per year, as shown by the figure 3 where the automotive electronic market volume in the past and in the next future is sketched.

The present conventional and hybrid vehicles have a countless number of small electric motor inside a car.

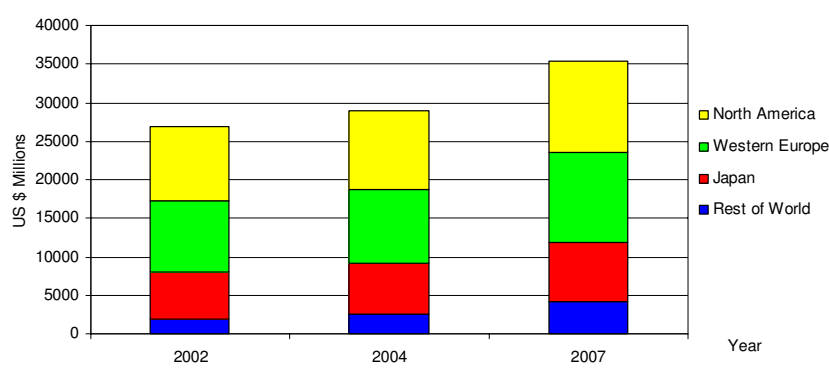

Fig. 3 World Market for Automotive Electronic (source: Reed Electronics Research)

But these electric motors are low-tech motors with limited efficiency, and all together they achieve a not anymore negligible weight. For instance in a luxury car their total weight could be easily more then 50 kilograms. This means that there are potential improvement margins.

Moreover in an HEV the electric drive is part of the driveline, hence large amount of energy is treated by the drive making mandatory the usage of an efficient drive. Therefore a suited drive design for ensuring a good efficiency and an acceptable reliability is necessary.

All above mentioned aspects justify the importance that nowadays the drive technology has for hybrid electric vehicle. Only well designed, correctly sized and conveniently controlled drives could really improve the vehicle in terms of performances, weight and costs.

Then activities of the Annex VII experts are welcome for improving the dissemination of knowledge on this topic.

Being impossible to generalize the topic, the experts of the Annex VII, in particular Arsenal Research as sub task leader, tried to point out some outlines describing the relevant configurations for $\mathrm{HEV}$ like the direct current machine, the permanently magnet synchronous machines (PMSM), and induction machines.

Moreover, the work gives an overview of the modeling methods and the control techniques for these machines.

In the following figures some of the arguments investigated by the working group are shown. Figure 4 gives the different rotor configurations for the PMSM machine. Whereas in figure 5 a rotor flux model configuration used as input for a torque control system can be see as example of control system for induction machine.

Such complex control techniques are necessary for achieving the best performance of the machine, in term of dynamic behavior and smoothness of the drive as well as for reducing as much as possible the copper and the iron losses inside the machine. 


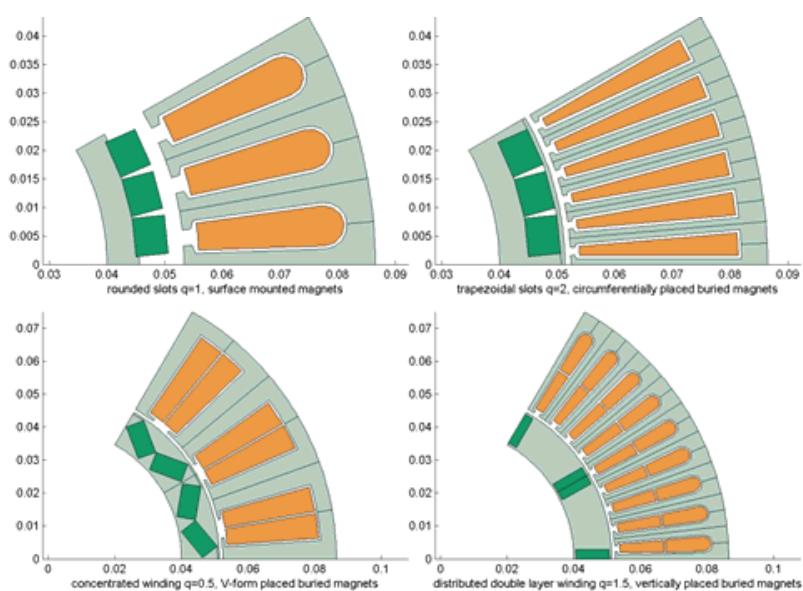

Fig. 4 Various examples of mechanical layout for inner rotor radial flux machines

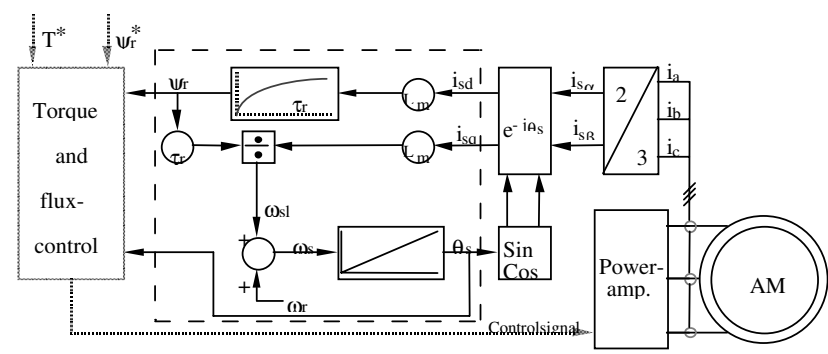

Fig. 5 Rotor flux model, incorporated in a torque and flux control system

\section{AUXILIARIES}

Besides the work on drives, the Annex VII has investigated the auxiliaries which normally undergo electrification in hybrid electric vehicle. In fact it is not only the traction system on board a vehicle that consumes power. The number of, and diversity of auxiliaries that are used either to just facilitate the operation of the vehicle, or to increase the comfort and usability of the vehicle is steadily increasing.

Some of these loads are mechanically driven via a belt from the crankshaft of the ICE, and yet some are electrically driven. In hybrid vehicles, and especially those without an ICE like the Fuel Cell vehicle, it is beneficial or necessary to drive the auxiliary loads with electric power. There are several advantages of doing so.

As first the load can be more freely placed within the vehicle since they do not have to be connected to the belt in the front of the ICE. This give both a weight and volume benefit. Moreover the efficiency can be significantly increased, since the possibilities to control the power consumption is enlarged when an electric machine is driving the load. The Air Conditioning (AC) compressor, as an example, can be driven at the optimal speed all the time. Instead in a conventional vehicle the AC compressor is tied hard to the ICE speed which is related to the vehicle speed, and not to the best speed for the AC compressor.

With their work the Annex VII members, in particular the Lund institute of technology as sub task leader, gives an overview of the sub-system and auxiliaries which are used in advanced vehicles. Moreover, as example of the auxiliaries' relevance, the energy savings evaluation for a city bus by the mean of the auxiliaries' electrification has been investigated.

\section{ENERGY STORAGES}

The energy storage devices are essential energy and power buffers for any hybrid electric vehicle. In a hybrid electric vehicle the regenerative braking and the engine load point shifting are possible only if a second energy source beyond the fuel is present on the vehicle. The main problem is that the energy densities of the available energy storages are relatively low if compared to the energy density of the fuels used in cars. Moreover the electrochemical energy storage devices are affected by a limited life and they require a specific management for avoiding life shortening and even safety issues. Above all that the energy storage systems are relative expensive device.

Therefore the energy storage system design for a hybrid electric vehicle is very complex and requires a particular attention during the powertrain development. It is necessary to define the best battery for a given application, the appropriate configuration and, last but not least, the suited operating strategy. Such tasks are challenging because the energy storage are affected by strong non linearities which makes their behavours hardly predictable if not complex simulation models are adopted.

Moreover the energy storages are in continuous development. For instance there is a big ferment around Lithium Ions cells since a couple of years, the cells have improved drastically their performances as well as their life expectation, on the other side for Lithium Ion cells there are still safety issues which need to be solved, as well as the cost reductions

All those things make hard an assessment for state of the art for energy storage systems. Despite that Vito, as sub task leader, addressed all those aspects giving an overview of the thematic.

The emphasis lies on the electrochemical energy storage systems, like batteries and ultracapacitors, but other storage systems like flywheels, hydraulic vessels are also considered.

The envisaged electric energy storage systems each have specific principles, characteristics and particular need for general and thermal management systems. On the other hand, there are also various hybrid electric vehicle configurations with different requirements. The work of the Annex VII gives an overview of the advantages/disadvantages and practical aspects of battery technologies and ultracapacitors which can be used in hybrid electric vehicle applications. 


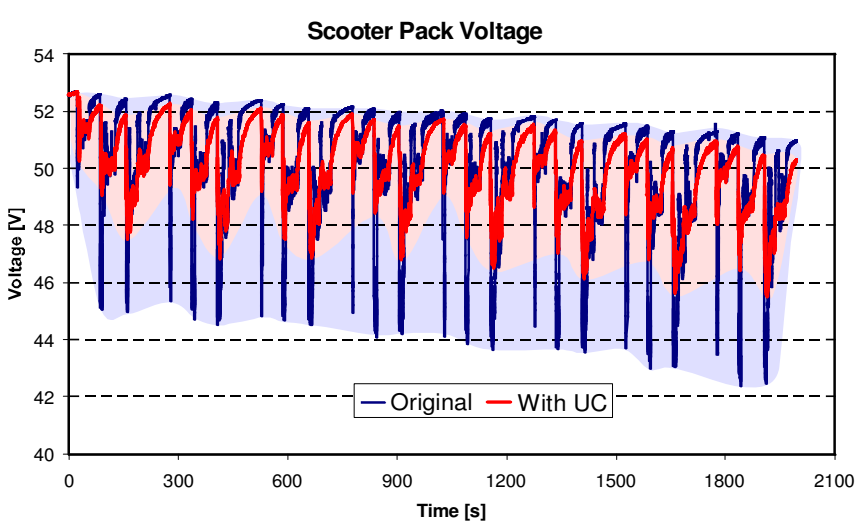

Fig. 6 Lead Acid battery pack voltage profile with and without Supercapacitor in parallel (Vito)

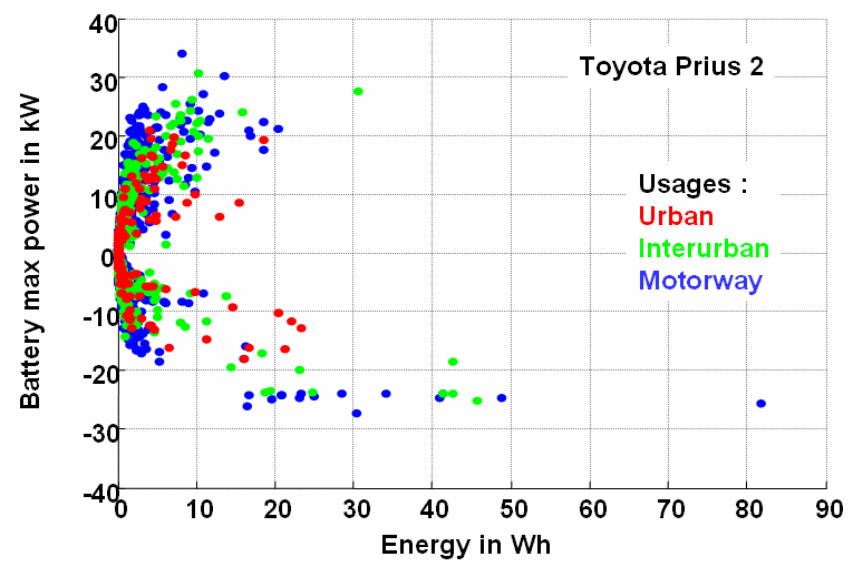

Fig. 7 NiMH battery pack micro-cycle characteristics under different drive cycles

Of course the work is limited to only likely candidates, and it is not aimed at specialists of battery technology, but should be conceived as thorough introduction to this topic.

As integration part of the work an intense information exchange between the Annex VII members has taken place. The Annex VII members have shared some of their own experiences on energy storage devices, as result interesting and fruitful discussions have been arisen.

As example of this virtuous circle in figure 6 the experience gathered by Vito research in the usage of Supercapacitor in parallel to lead acid battery is shown. This configuration could be a simple and inexpensive solution for improving the battery pack performance in particular in terms of life.

Another example of fruitful information sharing is shown in figure 7. There it is plotted the test bench measurements made on a Toyota Prius 2nd generation in the INRETS facilities. The plot contains a lot of information, primary it shows how the battery usage varies with the road configuration, then it shows the amount of regenerated energy and at which power level as well as the amount of energy spent for the acceleration.

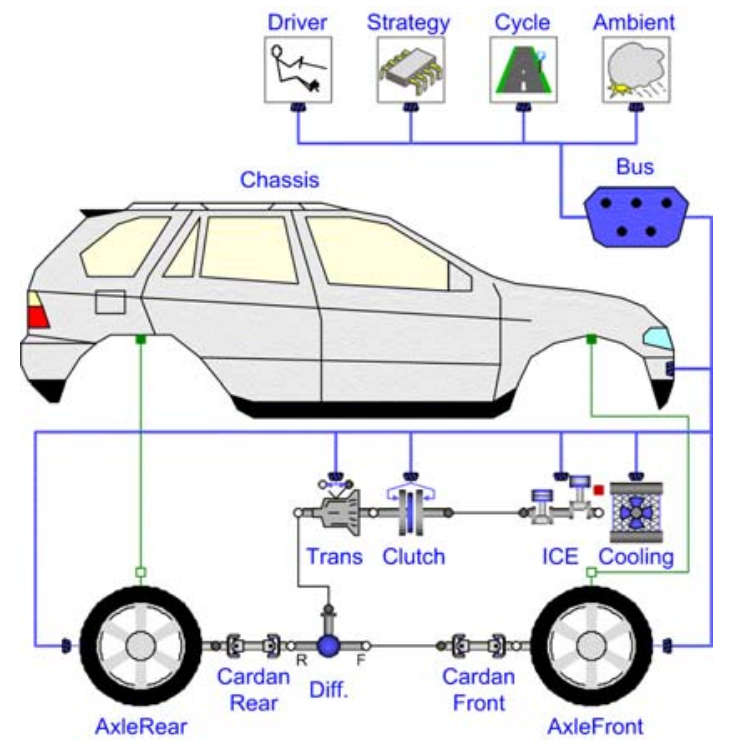

Fig. 8 Modelica-Dymola Arsenal Research simulation tool screenshot

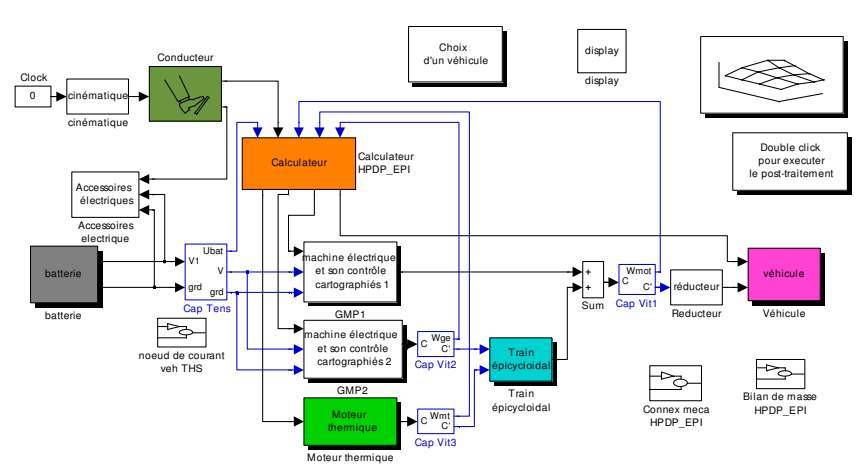

Fig. 9 Matlab-Simulink based INRETS simulation tool screenshot

Those information are useful not only for understanding the Toyota battery management strategy but for a better understanding of the Nickel metal hydride batteries.

\section{SIMULATION}

The simulations are pretty recent tools used for the vehicle development. But nowadays they have already become essential for properly design any hybrid electric vehicle. They reduce the development cost and the likelihood of design mistakes, moreover they are essential for developing advanced control strategies. Like in the case of the battery control strategy development which it is particularly complex and it needs specifically designed algorithms for estimating the State of Charge (SOC), the State of Health (SOH) and many other internal battery parameters.

By means of simulation tools the development of such strategies is simpler and if the adopted simulation tool has Hardware in the Loop (HIL) capabilities then also rapid validation on the test bench is possible. 


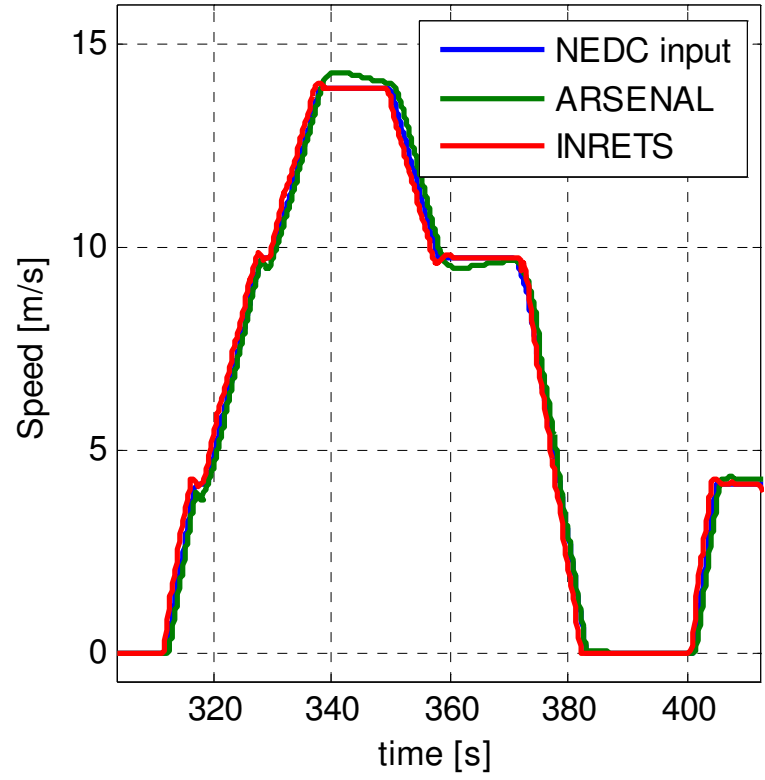

Fig. 10 Particular of an NEDC cycle

At the moment there is no standard software tool which is world-wide adopted and recognized for this application. Vehicle or Component simulators are at the moment various and each of them has different approach to the modeling. There is the PSAT software developed by Argonne which is a Matlab based, also INRETS has developed it own software VEHLIB, which it is forward type based on Matlab-Simulink with a Real Time version (VEHIL), or like the simulation software developed by Arsenal Research, which is object oriented, based on Modelica-Dymola and it is has also a Real Time interface.

It is not interest of the Annex VII to single out a simulators ranking. Rather it was considered valuable to share experience on different simulation tools for making a comparative assessment. In particular the Arsenal Research and INRETS started a sort of collaboration inside the Annex VII.

Arsenal Research and INRETS have elaborated models for the vehicles based on the measurements recorded with the hybrid powertrain test bench in the INRETS laboratories. Moreover they discussed the different modeling approach and the required inputs/outputs interfaces for the validation.

Figure 8 shows the highest layer of the Arsenal Research vehicle simulator tool, in this case a conventional vehicle is shown but with simple modifications any kind of vehicle could be simulated. For such advanced vehicle with electrical machines, and energy storages the Arsenal Research's Smart Electric Drive (SED) library is used. This SED commercial library includes all components necessary to simulate a modern electric drive system.

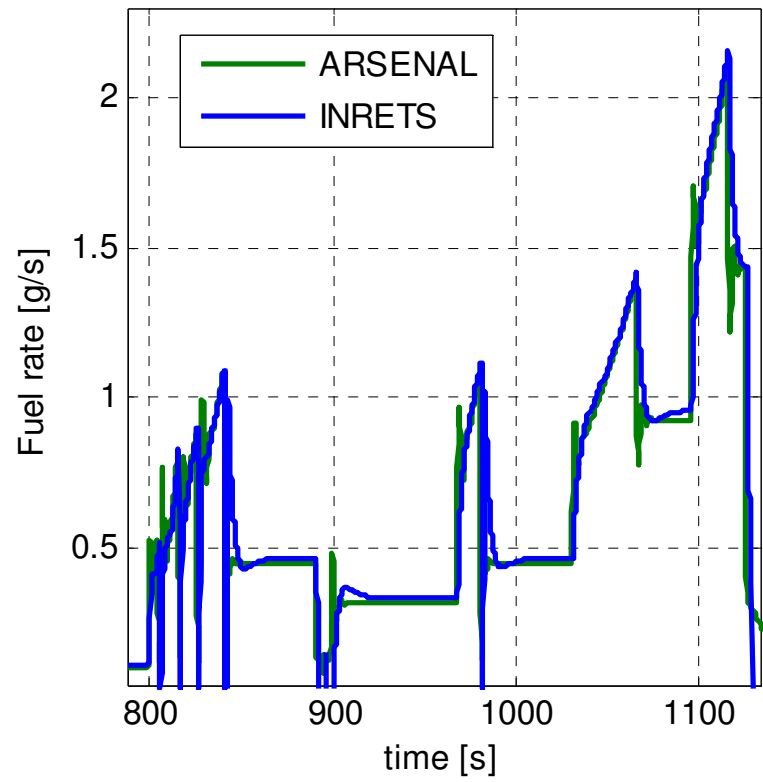

Fig. 11 Fuel rate simulation outputs

The model is developed in Dymola. Dymola is a simulation environment for Modelica, which is an open object-oriented simulation language. Such simulation language is taking place in many engineering applications, in particular few automotive OEMs have introduced it for advanced vehicle development.

On the other side, in figure 9 the screenshot of the INRETS vehicle simulator tool (VEHLIB) is shown. This software is Matlab-Simulink based, it considers different types of hybrid drivetrains and components and has been validated through measurements carried out on INRETS test benches.

As first step of this collaboration a conventional vehicle has been investigated. By using the test bench measurements of vehicle and its direct injected diesel engine, the two software tools have been tuned and validated. In figure 10 and 11 the simulation results are shown. It is possible to notice few small differences caused by the different simulation approach.

If slight differences appear in the dynamic behavior of the two models (see fig. 11), global discrepancies remain quite low with no more than $2 \%$ in overall European driving cycle fuel consumption, value which lies below the measurement system accuracy.

\section{CONCLUSIONS}

The Annex VII experts in the last two year with three scheduled meeting per year have created a valuable platform where important hybrid vehicles thematics are discussed with an independent approach.

In spite of the limited time and resources available the groups have demonstrated that added value could be created by a constructive discussion, and by the information exchange. The components for hybrid 
electric vehicle have been part of the Annex VII investigation, part of the result has been presented here. Further works is still needed because the theme is highly complex and continuous modifications of the scenarios take place. Furthermore the importance of such round table as virtuous circle for speeding up the introduction of advanced vehicles with a reduced environmental impact is clear to the working group participants.

\section{REFERENCES}

[1] VV.AA., Annex VII: Hybrid Vehicles Overview Report 2000 Chapter 4: "Components for hybrid vehicles", 2000

[2] M. Desbois-Renaudin, B. Jeanneret, F. Badin, J. Scordia, C. Plasse, R. Trigui, "Global Forward backward approach for a systematic analysis and implementation of hybrid vehicle management laws, application to a single shaft parallel hybrid power train " : 2004 European ELE-DRIVE Transportation conference \& Exhibition, Estoril, 2004.

[3] F. Badin, O. Briat, S. Olivier, B. Jeanneret, R. Trigui, B. Malaquin , "The use of batteries in hybrid vehicles" Congress IEEE Vehicle Power and Propulsion'04, Paris October 6-8 2004.

[4] F.V. Conte, "Optimierungsmöglichkeiten von elektrischen Energiespeichern in Hybridfahrzeugen", 10. Handelsblatt Jahrestagung Automobiltechnologien, April 2006, München.

[5] J.V. Gragger., D. Simic, C. Kral, H. Giuliani, F.V. Conte, F. Pirker, "A simulation tool for electric auxiliary drives in HEVs - The Smart Electric Drives library", FISITA World Automotive Congress 2006, Yokohama, Japan

[6] R. Trigui, B. Jeanneret, F. Badin, "Modélisation systémique de véhicules hybrides en vue de la prédiction de leurs performances énergétiques et dynamiques, construction de la bibliothèque de modèles VEHLIB", INRETS LTE : Revue Recherche Transports Sécurité n ${ }^{\circ}$ 83 Avril-Juin 2004, ISSN 0761-8980.

[7] D. Goodstein, "Out of Gas: The end of the Age of Oil", Cap.4., Ed. W.W. Norton \& Company, 2004.

[8] A.N. Brooks, "Perspectives on Fuel Cells and Battery Electric Vehicles", California Air resources Board Workshop, December 2002.

[9] S. Smets, P. Debal, F.V. Conte, M. Alaküla, D. Santini, M. Duvall, R. Winkel, F. Badin, "Overview of Battery Technology for HEV", Global Powertrain Congress September 2006, Novi,MI, United States.

\section{BIOGRAPHIES}

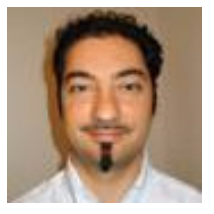

Fiorentino Valerio Conte was born 1972. He is graduated in Electrical Engineering at University of Pisa. In 2004 he received the Ph.D. degree from the University of Pisa. He is researcher of Arsenal Research's Monitoring Energy and Drives technologies business unit since 2003.

His research topics are focused on testing and modeling of energy storage systems. Since 2004 he is working in the IEA-HEV Annex-VII Task Force

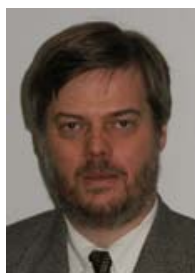

Patrick Debal graduated as Master in Mechanical Engineering at the Catholic University of Leuven in Belgium. In co-operation with Ford of Europe he made a dissertation about "Comprex Supercharging of Diesel Engines". He worked for more than 10 years at several levels in product development and R\&D for industry leaders like Atlas Copco. In January 1999 he joined the team Vehicle Technology of VITO as Senior Researcher. Since then he has been in charge of or involved with the development of hybrid systems and technology, on-board emission measurement and with vehicle energy and emission simulation models. During the last few years he has been focusing on the development of new and improved powertrain technology.

Francois Badin, aged 49, has been researcher at the Transports and Environment Lab. (LTE) of the INRETS since 1985 and is now

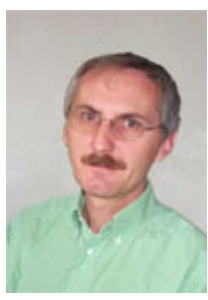
senior researcher, in charge of electric and hybrid vehicles activities at the INRETS.

F. Badin has got a Scientific Doctorate in Environmental Engineering from the University of Chambéry, France and a five years Engineering Degree in thermo-dynamic process at the National Institute of Applied Sciences in Lyon France.

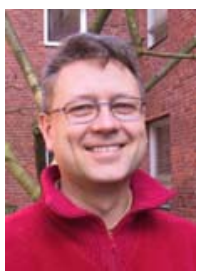

Mats Alaküla got his engineering education at Chalmers University of Technology, Göteborg, where he graduated in Electrical Engineering in 1986. From 1986 to 1989 he was a Ph.D student at the Department of Electrical Machines and Power Electronics and received his Licentiate degree at the same Department in 1989. From 1989 on he has been working in the field of electrical drives at the Department of Industrial Electrical Engineering and Automation (IEA) at the Lund Institute of Technology. In 1993 he received his Ph.D. degree and he is since April 1994 appointed as full professor in Industrial Electrical Engineering at IEA. His main field of interest is various aspects of electrical drives. 